\title{
Investigating 'Green BIM' in a Norwegian construction project: an institutional theory perspective
}

\author{
A. K. Lassen \& C. Merschbrock \\ Department of Civil Engineering and Energy Technology, \\ Oslo and Akershus University College, Norway
}

\begin{abstract}
Building Information Modelling (BIM) is catching on as the preferred tool in the Architecture, Engineering and Construction (AEC) industry. However, the models are seldom used for simulations such as energy calculations and environmental impact assessments. Yet we know that the AEC industry accounts for a large share of the world's environmental impacts. When BIM facilitates environmental sustainability in the built environment, it can be called 'Green BIM'. The research question explored in this article is 'To which degree is 'Green BIM' institutionalized in Norwegian construction projects, and how can this process be improved?' In order to understand why 'Green BIM' is slow to catch on, the authors used institutional theory as a lens to observe the regulative, normative and cultural-cognitive pressures present. Based on a case study conducted in a Norwegian construction project it is conceptualized how current regulations, incentives and perceptions all impact 'Green BIM'. The analysis is supported by interviews and documents. The case project was a highly profiled renovation project in the Oslo area - an office building which became not only a BREEAMNOR Outstanding building and a building which produces more energy than it consumes, but also one with zero emissions over its lifetime. Furthermore, it was modeled in BIM. Our findings show that 'Green BIM' was, for varying reasons, only practiced in a few instances. This study assists in understanding how culturalcognitive, normative and eventually regulative factors can speed up the implementation of sustainable building design with the help of BIM.

Keywords: green BIM, sustainable construction, environmental assessments, implementation, institutional theory.
\end{abstract}




\section{Introduction}

The architecture, engineering and construction (AEC) industry needs to improve performance of their products [1]. Environmentally correct building is among the most focused areas to achieve improvement in AEC, and needs to become mainstream [2]. Environmentally correct building is defined by the Norwegian government's Centre for Sustainable Production and Consumption as minimizing energy, material and water resource use in construction, operation and disposal of facilities, while at the same time minimizing hazardous emissions and adverse effects on health [3]. In short, such a building has concern for our resources and for the global, local and indoor environment. In this article, we refer to this as 'Green' building.

Novel design technologies, such as building information modelling (BIM), are seen to be key drivers for innovation in AEC [4]. There is reason to believe that this also applies when BIM is used to improve environmental performance - what we shall refer to as 'Green BIM'. BIM can save both money and carbon by minimizing wasteful processes and making timely informed decisions [5]. BIM will count, sort, calculate, and communicate, and has the potential to simulate accurately and efficiently. This means that the model can carry out solar and daylighting analyses, and geometric and functional data can be managed for advanced energy performance simulations and life cycle analyses (LCA) [6, 7].

Judging by the sales of BIM software, BIM - or at least $3 \mathrm{D}$ modelling - is extensively diffused in the industry. The technology is generally perceived as useful for improving a building's quality and reducing time use [8]. There is also evidence that BIM can assist in documentation for compliance and certification $[9,10]$. Nevertheless, there are differing opinions about the benefits of BIM [11]. Practitioners have concerns regarding technical aspects, work practices, data organization, and legal issues [12], thus limiting their full use of its possibilities. Therefore, it is "not a given that a set of well-trained, BIM-ready organizational actors makes use of BIM to jointly develop design solutions." [11].

We reason that if BIM, in itself an innovation, were fully exploited to facilitate Green building practices, this should stimulate change towards a more environmentally sustainable AEC industry. To obtain such a level of deployment, innovative technology must not only be well diffused in the industry, but also established as the natural way to work. Put differently - if 'Green BIM' is institutionalized in the planning and documentation of projects, this will promote the institutionalization of Green building on the whole.

In this study, we investigate to which extent BIM is currently employed to ensure and assess the environmental 'correctness' of buildings. The research question discussed is 'To which degree is 'Green BIM' institutionalized in Norwegian construction projects, and how can this process be improved?' Institutional theory has been employed to make sense of green developments in numerous fields, including organizations [13] and information systems [14, 15], but not yet in the context of the AEC Industry and BIM, as we hereby do.

To explore the role 'Green BIM' might play, we use a qualitative case study approach. The case project is an office renovation project in the Oslo area which 
became not only a BREEAM-NOR Outstanding building and a building which produces more energy than it consumes, but also one with zero greenhouse gas emissions over its lifetime. The project is influential as it is a pilot for the regional development programme FutureBuilt, in south eastern Norway. A collaboration consisting of a developer, a consulting firm, a major contractor, two large aluminium companies and an environmental organization have gone together to show that energy-positive buildings can be built in the cold north. Being a complex and prestigious project, naturally it was modelled in BIM. Many consultants and experts were involved, requiring close collaboration.

In the following sections, we present relevant concepts from the theoretical lens, focussing on Scott's Three Pillars of Institutions. Our findings and discussions are then structured around the said pillars, while also bearing other concepts in mind.

\section{Theoretical lens}

Institutional theory is typically associated with organizations, but also applies to behaviours and practices. According to Greif [16], an institution is a "system of rules, beliefs, norms, and organization that can jointly generate a regularity of behavior in a social system". While Roger's Diffusion of Innovations $[17,18]$ is a useful and much-used theory to understand the spread of new ideas, institutional theory explains how the innovations 'stick' in a community [19]. A useful example is clothes fashions - most spread like wildfire only to be replaced within the year by the next fad, while on the other hand jeans have been around for decades and can be seen as institutionalized.

Institutional theory is not one man's creation, rather an evolving theory with many contributing authors. At the centre, however, is a seminal paper where Scott [20] distinguishes between 3 pillars, or forces, which contribute to the embedding of new behaviours and practices.

The first pillar is Regulative, which essentially is enforced by (official) rules and regulations, but also (private) contracts. Next is Normative, voluntary yet standardized, as in standards, and certification- and educational-systems. Finally there is Cultural-Cognitive; an informal, intuitive and natural sharing of behaviours through copying, peer pressure and market forces.

The three pressures can be present in varying degrees, and not one is more important than the next. Nor do they occur in any specific order, though they may influence and interact, thus reinforcing each other [21], or self-reproducing, thus increasing the degree of institutionalization [19].

A much-used term in institutional theory is Legitimacy, meaning (according to Zucker and later authors) that the innovation must be desirable or acceptable, and appropriate [22-24]. To use a term from information systems theory [25], the tasktechnology fit needs to be good, which would require, amongst other things, a clear formulation of needs [26].

Oliver [27] identified five main responses to institutional pressures: acquiescence, compromise, avoidance, defiance and manipulation. Acquiescence accepts the innovation, by either unconscious habit, passive imitation, or strategic 
Table 1: Scott's Three Pillars of Institutions [20].

\begin{tabular}{|c|c|c|c|}
\hline & Regulative & Normative & Cultural-Cognitive \\
\hline $\begin{array}{l}\text { Basis of } \\
\text { compliance }\end{array}$ & Expedience & Social obligation & $\begin{array}{l}\text { Taken-for- } \\
\text { grantedness } \\
\text { Shared understanding }\end{array}$ \\
\hline $\begin{array}{l}\text { Basis of } \\
\text { order }\end{array}$ & Regulative rules & Binding expectations & Constitutive schema \\
\hline Mechanisms & Coercive & Normative & Mimetic \\
\hline Logic & Instrumentality & Appropriateness & Orthodoxy \\
\hline Indicators & $\begin{array}{l}\text { Rules } \\
\text { Laws } \\
\text { Sanctions }\end{array}$ & $\begin{array}{l}\text { Certification } \\
\text { Accreditation }\end{array}$ & $\begin{array}{l}\text { Common beliefs } \\
\text { Shared logics of } \\
\text { action } \\
\text { Isomorphism }\end{array}$ \\
\hline Affect & Fear Guilt/Innocence & Shame/Honour & Confusion/Certainty \\
\hline $\begin{array}{l}\text { Basis of } \\
\text { legitimacy }\end{array}$ & Legally sanctioned & Morally governed & $\begin{array}{l}\text { Comprehensible } \\
\text { Recognizable } \\
\text { Culturally supported }\end{array}$ \\
\hline
\end{tabular}

compliance. Compromise (by bargaining), avoidance (by concealment), or defiance (by dismissal) might be expected negative responses.

While Scott's three pillars are external pressures, DiMaggio pointed out that actors may also have an endogenous rational interest in change [28]. An institutional entrepreneur sees possibilities and shows strategic agency, supporting [29], or even taking a dominant role in [30] the creation of new practices.

\section{Method}

To see whether institutional theory might uncover to which extent 'Green BIM' is employed in a construction project, and not least which forces are at play (or not), we have conducted a case study involving clients, consultants, and contractors associated with the office renovation project. A case study was deemed an appropriate method to qualitatively study a large number of features in one naturally occurring case [31]. Our data was collected through semi-structured interviews with nine professionals (see Table 2).

Using interviews as the means of data collection gave us access to the experiences and interpretations of the informants [32]. Those interviewed were members of the planning team concerned with 'green' issues: representatives of the client/developer, a few of the engineering consultants, several representatives of the engineering, procurement and construction (EPC) contractor, and one subcontractor. All but the sub-contractor were members of the initial collaboration. 
The interviews were conducted in September 2014, when the design and construction of the office rebuild had recently been finalized.

Interview guides were designed as open questions. Most conversations took place at the designers' offices, while one was conducted via Skype, and all lasted from 60-75 minutes. Informed consent was sought in advance. All interviews were voice recorded, transcribed, and coded. Categories of results were derived from the data according to the relevant key concepts of institutional theory as outlined above.

Table 2: Interviews conducted.

\begin{tabular}{l|cl}
\hline Label & Firm & Role \\
\hline Client \#1 & Client/developer & First Project manager \\
Client \#2 & - " - & Second Project manager \\
Architect \#1 & Architects & Lead architect \\
Consultant \#1 & Engineering consultants & Technical consultants coordinator \\
Consultant \#2 & - " & Heating, ventilation, and AC \\
Contractor \#1 & EPC contractor & Project manager \\
Contractor \#2 & - “- & Green business officer \\
Contractor \#3 & - “- & BIM coordinator \\
Contractor \#4 & - “- & Global manager BIM \\
Subcontractor \#1 & Subcontractor solar systems & $\begin{array}{l}\text { Photovoltaic installations \& } \\
\text { facades }\end{array}$ \\
\hline
\end{tabular}

\section{Findings}

Our findings are structured around the three pillars of institutions - Regulative, Normative, and Cultural-Cognitive.

Regulative pillar. There are as of today no legal requirements regarding the use of digital tools for documenting buildings in Norway. If one chooses to submit the drawings for planning permission digitally, Industry Foundation Classes (IFC) files are to be employed. Incidentally, the building code on energy performance is currently being revised and will likely rule that all new constructions must calculate and document energy needs, no longer allowing a simple documentation of planned energy measures. This amendment, which is expected to come into force in 2016, will necessitate digital computing of energy performance, but still with no requirement of specific tools or BIM compatibility. The same goes for daylight simulations, etc. It is not likely that BIM requirements will become mandatory in the foreseeable future.

However, contracts also have a regulative effect. Disregarding a contract may have negative consequences, such as losing the job or being forced to put more 
resources into it. Certain requirements were agreed on by members of the planning team. "It was stipulated in the contract that the designing was to be done in BIM", Contractor \#1 told us. Furthermore, achieving an outstandingly sustainable building was a great hairy goal of the entire team. However, using BIM actively to attain that goal was not a stated requirement (Contractor \#1). Nor did the contract stipulate exactly which BIM tools were to be used to ensure a good workflow between them (Contractor \#3). When it did happen that certain actors were not contributing as agreed with regards to quality or scheduling, no sanctions were enforced: "The coordinator could have been more clear and ensured that everyone followed the premises for how to cooperate" (Architect \#1).

Normative pillar. Normative pressures include standards and certification systems. According to Contractor \#2, this project aspired to go beyond the Passivhaus criteria (for which Norway has a designated standard NS 3701). They had ambitions to build the first plus-house rehabilitation project, which would produce more energy than it consumed over its lifetime. There is no agreed standard on how to define a 'plus-house', so the project team had to make up the rules as they went along. "Other countries operate with primary energy (...) but this does not tie in with the methodology behind (embedded energy in) materials." (Contractor \#2).

In order to enable a positive energy budget over the building's lifetime, it was necessary to do an LCA of total energy use and to keep tabs on the embodied energy of all the building materials. Information on this can be found in a product's Environmental Product Declaration (EPD), if one exists. Again, this is a normative system, voluntary and not yet sufficiently diffused in the AEC industry. "Most manufacturers of products today don't even know what embodied energy is. Very, very many products have problems producing an EPD." "So we are forced to purchase products we really don't want because they are unable to document, and that is a pity." (Client \# 1 and 2).

Well into the project, it was decided to go for BREEAM-NOR certification as well. The Norwegian assessment system is built upon the British Building Research Establishment Environmental Assessment Methodology, the leading assessment method for buildings. "I would say that both BREEAM and energy labelling are a gigantic step of five years in the right direction." (Client \#1). This represents an accredited normative measuring stick for sustainability, along which the renovated office building attained the highest rating possible. BREEAM-NOR indicates that computer software is necessary to calculate daylight, energy performance and greenhouse gas emissions to gain credits, and the system will award credits if a recognized climate gas tool has been applied. Such tools are typically BIM-compatible, but there is no explicit requirement to apply BIM.

In spite of being an afterthought, the BREEAM-NOR rating became an important goal for the team. "The first project outside the UK to receive a BREEAM Outstanding level. We are very impressed", the head of Norwegian Green Building Council was cited saying in several professional journals, giving the designers a positive image in the community. Nevertheless, several of the actors were dismayed at the complexity, rigidity and bureaucracy of the system (Client \#1, Contractor \#2, Consultant \#1). 
Cultural-Cognitive pillar. Experience with the use of BIM in general and 'Green BIM' in particular varied. This influenced both the proficiency and the attitudes of the different actors.

The EPC contractor, having the BIM coordinator role as well as the overall project management, helped out in an attempt to bring all actors up to par. "We have BIM-modelled for (one of the consultants) so now already he will be better in the next project. He has tried and failed, maybe he will try and fail again, but eventually he will become good at it." (Contractor \#1). Thus, there was a fair amount of sharing of experience in the project. However, there was a limit to the capacity for this: "You don't have time to train people while you're dealing with the project because it goes so fast and you have a deadline. It's too late to start training people. So it's a matter of finding the right people." (Architect \#1). On the other hand: "It's important that people are in a project while they are taking a course. Because if you are in a course and not working in a Revit project, you forget it. It's wasted." (Consultant \#2).

The BIM coordinator hoped to base the LCA on embodied energy data straight from the BIM model. "We have a methodology where you could basically set up a project in Revit within a couple of hours, and you're ready to knock out the carbon footprint at any time after that", Contractor \#4 told us. However, he went on: "it requires that the architect and/or the structural engineer is prepared to do some initial work with the materials in the model. They have to basically load the model with carbon footprint data." As it turned out, this did not happen and the LCA was worked out using a spreadsheet.

Also for daylight and energy performance simulations, calculations have been done in the traditional way. We asked Contractor \#2 whether they had imported the geometry from the BIM-model into the simulation softwares: "No, there have been dimensions from the architect; there's been a ruler and calculator; working out volumes and areas." According to Subcontractor \#1, "to calculate energy consumption, it does not matter if that room is five millimetres wider or not. But when it is about putting doors in, cables, ventilation, carpets, then it matters. (...) We have to choose our weapons right."

Speaking of LOD (Level of Detail), Client \#1 was dismayed at how much time and money went into, firstly, just deciding on what was to be delivered, and then in delivering work which was not appropriate. "It simply hasn't functioned, the tool!" Then he corrected himself: "Not the tool; the people. It's the people who aren't functioning. (...) Knowledge is what is in short supply."

The overall value of BIM for achieving 'Green' design was not apparent to all. As Contractor \#1 saw it: "BIM is a tool for rationalizing the building process, avoiding errors, structuring the design phase, and so on. BIM's role in 'green' building is not obvious to me." Others, however, saw differently; when asked whether BIM had a role to play in 'Green', Contractors \#3 and \#4 answered "Yes!" and "Yes, definitely!". Yet others were undecided, as Client \#1: "I don't understand why you are linking it to sustainability; (...) I don't understand BIM BREEAM; I don't see the connection. (...) Actually, I've heard that you can document BREEAM through BIM! Then it starts getting interesting!" 


\section{Discussion}

With such ambitious 'green' goals as the office refurbishment project had, one might have thought that BIM had been used extensively and had contributed substantially to its success. When we started this study, we did indeed expect to find this, but as our findings show, this was not the case. Therefore, our focus shifted to examining why not. Our research question became: 'To which degree is 'Green BIM' institutionalized in Norwegian construction projects, and how can this process be improved?' We will start by checking the legitimacy of the innovation, before discussing to which degree the three pillars of institutionalization are present. Then we reflect upon the responses we have observed in the individual firms, and the measures which might be taken to improve adoption.

It is safe to say that the legitimacy - the appropriateness of the innovation - is mostly in place. There are certainly no laws against using BIM and associated software to calculate and document performance, and BREEAM-NOR will never deduct points for evidence of BIM use. Whether the method is perceived as desirable and appropriate amongst the team members, is however questionable. The level of confidence in the usefulness of the method appeared to be dependent on the level of BIM knowledge. The level of actual usefulness, on the other hand, depended on the BIM knowledge level of the weakest link in the team, and on the degree of communication between its members. With adequate knowledge one will also be able to 'choose the right weapon' for the job at hand, ensuring a good task-technology fit.

Regulative pillar. Since current performance based building regulations do not specify the use of BIM in any way, the regulative pressures at force were limited to the contract between the design team members. While there was a contract stipulating that BIM was to be used for the designing, it did not specify that the model was to be loaded with environmental data, nor that simulations must be run on the model. When certain actors did not comply with the requirements to deliver even basic 3D geometrical data on time, no sanctions were enforced, thus rendering the potential regulative pressures weak.

Normative pillar. BREEAM-NOR can be said to be a powerful normative force towards institutionalizing 'Green', however it is not a force affecting 'Green BIM'. It is desirable and quite possible to amend this. The opportunity for influencing content is much greater with certification systems than with laws. In order to maintain its standing in the market as a popular system, BREEAM-NOR needs to keep evolving, improving the user friendliness as well as the methods it encourages. It can be added that as it is not compulsory, the certification system can specify methods that require effort and investment on the part of the user to a much greater degree than official rules and regulations can.

The lack of available EPDs is a real snag in the establishing of rational documentation for sustainable buildings. Only when the majority of serious suppliers of building materials and products come up with proper environmental documentation, will it be possible to ensure selection of the best products from a 
life cycle point of view. And only when this data is included in the BIM model, will it become a valuable element of the 'Green BIM'.

Cultural-Cognitive pillar. Cultural-Cognitive pressures were definitely at play in the case studied. The goal of being the first plus-house and the first Outstanding BREEAM-NOR project in Norway were undoubtedly influenced by the perception that 'Green' is a positive thing, and excelling will put you in a good position. This in turn sends a strong signal to others in the field. Within the collaboration, while all were in agreement that a sustainable project was desirable, the use of BIM to achieve this was less obvious to certain members. Again, good knowledge of the possibilities and potentials of 'Green BIM' would be a condition to see the advantages. Working in close collaboration with more proficient colleagues is an efficient way to become aware of the hidden virtues of the method.

Knowledge has been mentioned several times now. We found ourselves pondering which role education plays in the process of institutionalization. Upon reflection, it becomes clear that formal education is a normative factor. It is voluntary, yet relatively standardized. While there will be a degree of sharing of knowledge through the informal process of cognitive mimetics, this is not an efficient way to learn due to limited time and funds in a project. BIM, and thereby also 'Green BIM', is complex and advanced, and requires full immersion. We argue that a solid emphasis on BIM at institutions of engineering education will be vital to both diffusion and embedding of the innovation, and add this to the normative pillar.

Strategic agency is the most proactive response firms can enact towards institutional pressures. Responding with conscious compliance means that the organization sees potential benefits in the innovation and positions itself at the head of the pack. We observed this with the client/developer, architects, subcontractor, and several of those representing the EPC contractor. Still, one of the senior professionals had no interest and saw no advantages in applying BIM, and responded with dismissal of the method. The consultants were lagging behind, and avoided compliance by concealing their inadequate capabilities, making an excuse of the obstacles in training people on the job. Such negative reactions might simply affect the efficiency of the individual. However, if interdependency is high, non-compliance on the part of one actor may slow down the whole team and impede institutionalization in general.

Strategic agency could be nurtured within the individual firms by the help of institutional entrepreneurs. One likely group of actors who might take this role are the young, newly educated and BIM savvy engineers. This we saw in the young professionals, especially Contractors \#1 and 3. Another group are the managerial teams, who have the mandate to stipulate what goes into contracts and how agreements are to be enforced, such as we observed to a certain degree in Client $\# 1$, Architect \#1 and Contractor \#4. Only thus can the firms truly take strategic action to reap the benefits of BIM. 


\section{Contributions}

Our contribution to practice within the AEC industry is that we have uncovered some of the forces which should be strengthened in order to ensure institutionalization of 'Green BIM'. We have heard the opinions of expert professionals who have attempted to work with the system, and analysed why the system fell through all the while the project succeeded. As ever more projects aspire to be sustainable and at the same time become more complex, the need for more efficient digital tools, simulation systems, and cooperative work procedures emerges. Applying the appropriate pressures may speed up the application and evolution of better-suited tools and systems, leading ultimately to better performing buildings. We have identified pressures that are lacking or weak, based on Scott's three pillars, as shown in Table 3.

Table 3: Forces in need of strengthening.

\begin{tabular}{l|lll}
\hline & Regulative & Normative & Cultural-Cognitive \\
\hline $\begin{array}{l}\text { Forces in } \\
\text { need of }\end{array}$ & Enforcing of & BREEAM-NOR & Sharing of knowledge \\
strengthening & contracts for use of & EPD data & Inst. entrepreneurs \\
& BIM & Education & Informed management \\
\hline
\end{tabular}

The contribution to research is that we have looked at the current situation through a fresh lens, thus uncovering specific formal and informal hindrances to full implementation of a relatively recent innovation. While the spreading of BIM and 'Green BIM' in the AEC industry has been researched by many, this study of how it 'sticks' is a novel approach.

A study based on only one case in Norway will not represent the opinions of all professionals working with BIM, and the very ambitiousness of this project makes it stand out somewhat from most undertakings. From an international perspective, the state of the various 'pillars' will vary from country to country. Regulations are structured differently, different certification systems have been adopted, education systems differ, and the very culture in the industry will be differing - leading to a unique degree of institutionalization of 'Green BIM'. It would be interesting to do a cross-cultural study in several countries to investigate the differences, learn from each other, and thus contribute further to the evolution of sustainable construction.

\section{Conclusion}

This study has shown that institutionalization of BIM to improve environmental performance in buildings has a long way to go. We have indicated which institutional pressures are in place, and which are weak. We have also pointed out the consequences and suggested where more effort should be laid down to ensure speedy adoption. The three pillars of institutionalization, namely the (1) Regulative, (2) Normative and (3) Cultural-Cognitive, could all be strengthened. 
The AEC industry in Norway should focus on (1) writing contracts that stipulate the use of BIM also for environmental performance, and enforcing them, (2) encouraging the use of BIM and EPDs through environmental assessment systems such as BREEAM-NOR, and improving the BIM education at engineering colleges, and (3) placing people with a solid understanding of BIM and sustainability matters in key positions.

\section{References}

[1] Egan, J., Rethinking Construction, Department of Environment, Transport and the Region: London, 1998.

[2] Kibert, C.J., Sustainable Construction: Green building design and delivery. Wiley: New Jersey, 2012.

[3] Jacobsen, P.A. \& Bramslev, K.T., GRIP byggprosjektering, GRIP: Oslo, 1998.

[4] Boland Jr, R.J., Lyytinen, K. \& Yoo, Y., Wakes of innovation in project networks: The case of digital 3-D representations in architecture, engineering, and construction, Organization Science, 18(4), pp. 631-647, 2007.

[5] Royal Institution of Chartered Surveyors, What is BIM?, http://www.rics.org/uk/knowledge/glossary/bim-intro/

[6] Häkkinen, T. \& Kiviniemi, A., Sustainable building and BIM. Proc. of the 2008 World Sustainable Building Conference, Melbourne. 2008. https://www.rakennustieto.fi/kortistot/rane/material/attachments/5oJ5FjlG F/5xDib83oW/Sustainable_building_and_bim_T_Hakkinen.pdf

[7] Krygiel, E. \& Nies, B., Green BIM: Successful Sustainable Design with Building Information Modeling, John Wiley \& Sons: Indianapolis, 2008.

[8] Merschbrock, C. \& Munkvold, B.E., A research review on Building Information Modeling in construction - An Area Ripe for IS Research. Communications of the Association for Information Systems, 31(10), pp. 207-228, 2012.

[9] Kristiansen, M., Vurdering av egnethet for implementering av BREEAMNOR, Helse og Inneklima, i BIM. Ås, 2012.

[10] Azhar, S., et al., Building Information Modeling for sustainable design and LEED ${ }^{\circledR}$ rating analysis. Automation in Construction, 20(2), pp. 217-224, 2011.

[11] Merschbrock, C., Unorchestrated symphony: The case of interorganizational collaboration in digital construction design. Journal of Information Technology in Construction, 17(22), pp. 333-350, 2012.

[12] Gu, N. \& London, K., Understanding and facilitating BIM adoption in the AEC industry. Automation in Construction, 18(9), pp. 988-999, 2010.

[13] Jennings, P.D. \& Zandbergen, P.A., Ecologically Sustainable Organizations: an Institutional Approach. Academy of Management Review, 20(4), pp. 1015-1052, 1995.

[14] Swanson, E.B. \& Ramiller, N.C., The Organizing Vision in Information Systems Innovation. Organization Science, 8(5), pp. 458-474. 1997. 
[15] Butler, T., Compliance with institutional imperatives on environmental sustainability: Building theory on the role of Green IS. The Journal of Strategic Information Systems, 20(1), pp. 6-26, 2011.

[16] Greif, A., Institutions and the Path to the Modern Economy: Lessons from medieval trade, Cambridge University Press, 2006.

[17] Rogers, E.M., Diffusion of innovations, Simon and Schuster; New York, 1962.

[18] Rogers, E.M., Diffusion of innovations, Fifth edition, Simon and Schuster: New York, 2003.

[19] Colyvas, J.A. \& Jonsson, S., Ubiquity and legitimacy: Disentangling Diffusion and Institutionalization. Sociological Theory, 29(1), pp. 27-53, 2011.

[20] Scott, W.R., Institutions and Organizations. Sage Publications: Thousand Oaks, 1995.

[21] Scott, W.R., Approaching adulthood: The maturing of institutional theory. Theory and Society, 37(5), pp. 427-442, 2008.

[22] Meyer, J.W. \& Rowan, B., Institutionalized Organizations: Formal structure as myth and ceremony. American Journal of Sociology, 83(2), pp. 340-363, 1977.

[23] Zucker, L.G., The role of Institutionalization in cultural persistence. American Sociological Review, 42(5), pp. 726-743, 1977.

[24] Suchman, M.C., Managing legitimacy: Strategic and institutional approaches. Academy of Management Review, 20(3), pp. 571-610. 1995.

[25] Goodhue, D.L. \& Thompson, R.L., Task-Technology Fit and individual performance. Management Information Systems Quarterly, 19(2), pp. 213236, 1995.

[26] Merschbrock, C., Lassen, A.K. \& Tollnes, T., Integrating BIM and gaming to support building operation: The case of a new hospital. Proc. of Norsk konferanse for organisasjoners bruk av informasjonsteknologi. Høgskolen i Østfold, 22(1), 2014.

[27] Oliver, C., Strategic responses to institutional processes. Academy of Management Review, 16(1), pp. 145-179, 1991.

[28] DiMaggio, P.J., Interest and agency in institutional theory. Institutional Patterns and Organizations: Culture and environment, ed. Zucker, pp. 322, 1988.

[29] Dacin, M.T., Goodstein, J., \& Scott, W.R., Institutional theory and institutional change: Introduction to the special research forum. Academy of Management Journal, 45(1), pp. 45-56, 2002.

[30] Wahid, F. \& Sein, M.K., Institutional entrepreneurs: The driving force in institutionalization of public systems in developing countries. Transforming Government: People, Process and Policy, 7(1), pp. 76-92, 2013.

[31] Gomm, R., Hammersley, M. \& Foster, P., Case study method: Key Issues, Key Texts, Sage, London, 2000.

[32] Walsham, G., Doing interpretive research. European Journal of Information Systems, 15(3), pp. 320-330, 2006. 